JPdK Volume 3 Nomor 1 Tahun 2021 Halaman 90-96

JURNAL PENDIDIKAN dan KONSELING

\title{
Peran Orang Tua Dalam Pelaksanaan Pembelajaran Daring Pada Siswa Sekolah Dasar Di Pulau Rona Kecamatan Bangkinang
}

\author{
Fenny Indriyani ${ }^{1}$, Yusnani ${ }^{2}$ \\ Prodi Pendidikan Bahasa Inggris \\ Fakultas Ilmu Pendidikan \\ Universitas Pahlawan Tuanku Tambusai \\ Email: fennyindriyani11@gmail.com ${ }^{1}$, yusnani311@gmail.com ${ }^{2}$
}

\begin{abstract}
Abstrak
Orang tua berperan besar agar anaknya tetap belajar di rumah. Penelitian ini bertujuan untuk mengetahui bagaimana peran orang tua siswa sekolah dasar dalam membimbing anaknya selama pembelajaran daring dan apa yang dilakukan orang tua ketika menghadapi kesulitan selama pembelajaran daring. Metode yang dilakukan dalam penelitian ini adalah metode penelitian kualitatif deskriptif. Teknik pengumpulan data dilakukan dengan wawancara. Peserta dalam penelitian ini adalah orang tua dari siswa sekolah dasar dari kelas 1 s/d 6 SD di Pulau Rona, Kecamatan Bangkinang. Peserta tersebut berjumlah 15 orang. Analisis dalam penelitian ini disajikan secara kualitatif deskriptif. Hasil penelitian ini menunjukkan bahwa: a) Orang tua telah berperan dalam membimbing dan mengontrol anaknya selama pembelajaran daring. b) Orang tua berhasil mengatasi kesulitan pada anak dengan memberikan les tambahan dan memberikan fasilitas belajar daring. c) Orang tua mendukung anaknya selama belajar daring dengan memberikan apresiasi.
\end{abstract}

Kata Kunci: Pembelajaran daring, peran orang tua.

\begin{abstract}
Parents are very important in guiding their children during online learning. Especially during this pandemic, parents play a big role in keeping their children studying at home. This study aims to determine the role of parents of elementary school students in guiding their children during online learning and what parents do when facing difficulties during online learning. The method used in this research is a descriptive qualitative research method. The data collection technique was done by interviewing. Participants in this study were parents of elementary school students from grades 1 to 6 of SD on Pulau Rona, Bangkinang. The participants totaled 15 people. The analysis in this study is presented in a qualitative descriptive manner. The results of this study indicate that:a) Parents have a role in guiding and controlling their children during online learning. b) Parents are successful in overcoming difficulties for their children by providing additional tutoring and providing online learning facilities.c) Parents support their children during online learning by giving appreciation.
\end{abstract}

Keywords: Online learning, The role of parents

\section{PENDAHULUAN}

Sejak ditetapkannya corona virus disease 2019 (Covid-19) sebagai wabah nasional pada 11 Maret 2020, pemerintah mengeluarkan kebijakan agar seluruh masyarakat untuk melakukan social distancing atau menjaga jarak. Hal ini berdampak pada system pendidikan di Indonesia, terutama di Kota Bangkinang khususnya pulau rona. Setelah diberlakukannya social distancing, sistem pendidikan di Indonesia berubah drastis, model pembelajaran di semua tingkat pendidikan sejak dari prasekolah, pendidikan dasar sampai perguruan tinggi mulai melakukan adaptasi 
dengan memberlakukan system daring (online). Saat ini, hampir semua orang tua siswa di Indonesia diharuskan mendampingi anaknya belajar di rumah. Para orangtua mengakui bahwa menjelaskan berbagai mata pelajaran dan menemani anak-anak mengerjakan tugas-tugas sekolah tidak semudah yang dibayangkan.

Setelah Kemendikbud menerapkan pembelajaran daring, ternyata konsep pembelajaran daring memiliki konsep yang hampir sama dengan e-learning. Pembelajaran dalam jaringan (daring) merupakan istilah pembelajaran e- learning yang memiliki konsep lebih luas dari pada online learning. (Nurkolis \& Muhdi, 2020). Menurut Isman, pembelajaran online adalah penggunaan internet selama proses pembelajaran. Siswa dapat menggunakan berbagai aplikasi untuk berinteraksi dengan guru, seperti kelas, video conference, telepon atau live chat, zoom atau grup melalui whatsapp.(Dewi, 2020). Sedangkan Elearning adalah suatu sistem atau konsep pendidikan yang memanfaatkan teknologi informasi dalam proses belajar mengajar. (A et al., 2017) E-learning bisa berbasis computer atau disebut dengan computer-based learning dan berbasis online learning.

Pada dasarnya pembelajaran online atau elearning adalah pembelajaran jarak jauh (PJJ)(Belawati, 2019). Pembelajaran jarak jauh merupakan metode pengajaran yang memisahkan antara guru dan siswa(Irawati \& Santaria, 2020) Pemisahan mungkin karena jarak fisik atau berdasarkan waktu, sehingga situasi ini mencegah pembelajaran tatap muka(Uno, 2007) E-learning merupakan salah satu jenis materi pembelajaran yang dapat digunakan untuk mengkomunikasikan materi dan melaksanakan penilaian pembelajaran melalui penggunaan media internet, intranet atau alat elektronik lainnya(Hartley, 2001) E-learning mengacu pada penggunaan Internet dan teknologi digital lainnya untuk menciptakan pengalaman yang dapat mendidik atau mengajar orang lain(Horton, 2001)

Pembelajaran daring bertujuan untuk menyediakan layanan pembelajaran online berkualitas tinggi, yang besar dan terbuka, dan dapat menarik lebih banyak peminat(Adhe, 2018). Aspek yang perlu diperhatikan saat menerapkan elearning antara lain perencanaan, pengukuran kebutuhan siswa, sistem pendukung, kapabilitas guru, desain materi, platform yang tepat, dan evaluasi hasil belajar siswa(Lynch, 2002). Namun, dalam pelaksanaannya, pembelajaran daring memiliki banyak kelebihan dan kelemahan. Dari segi kelebihan, pembelajaran daring memberikan waktu dan tempat yang fleksibel (Yuangga \& Sunarsi, 2020), menciptakan suasana belajar baru(Sari, 2015), Menghemat biaya transportasi, siswa dapat belajar sesuai dengan metode pembelajarannya sendiri, memiliki lebih banyak waktu untuk berkumpul dengan anggota keluarga, dan siswa memiliki lebih banyak tanggung jawab, kreativitas dan kemandirian(Ramanta \& Dwi Widayanti, 2020). Kelemahan sistem pembelajaran online adalah anak-anak tidak dapat berkonsentrasi karena situasi dan kondisi di rumah yang tidak mendukung proses pembelajaran online dengan baik(Sari, 2015). Selain itu, pembelajaran online menyebabkan kurangnya interaksi antara pendidik dan siswa serta antar siswa (Yuangga \& Sunarsi, 2020), tugas yang diberikan sangat banyak, penggunaan kuota lebih boros dan hanya bergantung pada koneksi(Ramanta \& Dwi Widayanti, 2020), dan kesulitan dalam memahami materi(Jamil \& Aprilisanda, 2018)

Ada beberapa aspek dalam pembelajaran daring yang harus dipenuhi yaitu adanya siswa, guru dan teknologi dan peran serta orang tua siswa, karena dalam pembelajaran, orang tua siswa juga menjadi aspek yang penting untuk menunjang kelancaran pembelajaran daring(Andini \& Widayanti, 2020). Banyak ahli menyatakan bahwa orang tua merupakan pendidik pertama dan utama. Menurut Drost (1998), Orang tua adalah yang paling bertanggung jawab terhadap pendidikan(Kawuryan, 2016). Orang tua mempunyai kedudukan yang utama, karena orang tua merupakan pendidik pertama dalam keluarga. Mereka sangat memperhatikan pengetahuan umum dan khusus, artinya orang tua memberikan pelayanan kepada anaknya dalam skala global.(Astuti, 2013)

Dalam kehidupan modern saat ini, kita dapat melihat bahwa beberapa orang tua sangat memperhatikan perannya dengan meningkatkan pendidikan dan perkembangan ilmu pengetahuan dan teknologi, memberikan kesempatan kepada masyarakat dan memberikan kesempatan kepada perempuan untuk meraih kesuksesan seperti halnya laki-laki. Oleh karena itu, terlihat jelas banyak seorang ibu yang bekerja penuh waktu di luar ruangan dapat berdampak pada peran lain(Astuti, 2013). Berdasarkan uraian di atas, maka peneliti tertarik untuk mengetahui lebih jauh respon dan peran orang tua siswa Sekolah Dasar di Pulau Rona terhadap pembelajaran daring yang baru diberlakukan.

Orang tua sangat berperan penting dalam membimbing anak selama pembelajaran daring. Apalagi pada masa pandemic ini, orang tua 
berperan besar agar anaknya tetap belajar di rumah. Menurut (Aziza \& Yunus, 2020) peran orang tua dengan membuat jadwal anak untuk memperhatikan kegiatan belajar anak di rumah, dapat memberikan semangat bagi anak selama belajar di rumah. Selain itu, Orang tua berperan dalam mendidik anak, yang dapat memenuhi kebutuhan anak, memberikan pemahaman spiritual, pengawasan, motivasi dan fasilitas bagi anak. Bantuan belajar anak dapat dilihat dari kesulitan orang tua membantu anaknya menyelesaikan tugas, menjelaskan materi yang kurang dipahami anak, dan respon yang baik terhadap semua pembelajaran online di sekolah.(Yulianingsih etal., 2020). Sehingga muncullah korelasi positif antara pola asuh belajar online di rumah atau bimbingan orang tua terhadap motivasi belajar siswa selama masa pandemic ini.(Kurnianto \& Rahmawati, 2020)

Disisi lain, adanya kendala yang di alami oleh orang tua dalam membimbing anak selama pembelajaran daring. Dalam penelitian yang dilakukan oleh (Nugraheny\& Mahasiswi, 2020) menemukan kendala bagi orang tua mengenai tanggung jawab sebagai guru alternatif di rumah selama pandemi tidak bisa dianggap remeh karena harus berbagi waktu dengan pekerjaan rumah dan mengajarkan anak-anak selama pembelajaran online. Selain itu, orang tua tidak dapat memahami pembelajaran anak-anaknya. Oleh karena itu, sebenarnya dalam hal ini peran guru sangat berarti dan tidak dapat tergantikan. (Susanto \& Akmal, 2019)Untuk mengatasi hal ini, dibutuhkan kolaborasi antara peran orang tua dan guru untuk meningkatkan hasil belajar anak selama pembelajaran daring. Yang mana orang tua dan guru harus terlibat dalam membimbing anak selama pembelajaran daring.(Hakim, 2020). Maka dari itu, dalam penelitian ini berfokus pada peran orang tua dalam membimbing anak selama belajar daring.

\section{METODOLOGI PENELITIAN}

Jenis penelitian yang digunakan dalam penelitian ini adalah kualitatif deskriptif. Menurut Nana SyaodihSukmadinata (2011: 73), penelitian deskriptif kualitatif ditujukan untuk mendeskripsikan dan menggambarkan fenomenafenomena yang ada, baik bersifat alamiah maupun rekayasa manusia, yang berfokus pada karakteristik, kualitas, keterkaitan antar kegiatan. Selain itu, Penelitian deskriptif tidak memberikan perlakuan, manipulasi atau pengubahan pada variabel- variabel yang diteliti, melainkan menggambarkan suatu kondisi yang apa adanya.

Adapun Penelitian kualitatif merupakan prosedur penelitian yang menghasilkan data berupa ucapan atau tulisan dan perilaku orangorang yang diamati(Melia, 2020). Penelitian kualitatif adalah penelitian yang dilakukan dalam konteks alamiah dan menyeluruh(Daulay, 2020). Penelitian kualitatif bertujuan untuk mengamati, mengamati dan menghayati masalah yang akan dikaji dengan fenomena yang kompleks, dan harus dipelajari secara menyeluruh (PPS UNP, 2004: 18). Untuk memperoleh gambaran umum penelitian kualitatif, penelitian memiliki beberapa ciri utama, yaitu (1) lingkungan alam merupakan sumber data langsung; (2) manusia sebagai alat atau alat utama untuk mengumpulkan data; (3) analisis data dilakukan secara induktif; dan (4) Penelitian analitik dan deskriptif (Suharsimi, 2007). Dalam hal ini, penelitian kualitatif adalah proses penggalian informasi atau informasi yang digunakan sebagai data peristiwa, kemudian menginterpretasikan fakta berdasarkan gejala yang diamati..

Berdasarkan keterangan dari beberapa ahli di atas, dapat ditarik kesimpulan bahwa penelitian deskriptif kualitatif yaitu rangkaian kegiatan untuk memperoleh data yang bersifat apa adanya tanpa ada dalam kondisi tertentu yang hasilnya lebih menekankan makna. Tujuan menggunakan metode ini ingin mengungkapkan dan menyajikan apa adanya tentang peran orang tua dalam pelaksanaan pembelajaran daring pada siswa Sekolah Dasar di Pulau Rona, Kecamatan Bangkinang.

Peserta dalam penelitian ini adalah orang tua dari siswa sekolah dasar dari kelas 1 s/d 6 SD di Pulau Rona, Kecamatan Bangkinang. Peserta tersebut berjumlah 15 orang. Untuk mencapai tujuan penelitian, data diambil dengan proses mewawancarai peserta. Wawancara kualitatif digunakan untuk mengumpulkan data dari 15 orang tua. Wawancara dilakukan selama kurang lebih 15 menit dengan 10 pertanyaan yang di ajukan. Pertanyaan- pertanyaan yang diajukan tersebut berhubungan dengan bagaimana peran orang tua mendidik anak selama pembelajaran daring. 


\section{HASIL PENELITIAN DAN PEMBAHASAN}

Tabel pertanyaan dan jawaban terhadap responden

\begin{tabular}{|c|c|c|}
\hline No & Pertanyaan & Jawaban responden/orang tua \\
\hline 1. & $\begin{array}{l}\text { Bagaimana pandangan Anda mengenai } \\
\text { pembelajaran daring yang telah } \\
\text { berlangsung selama hampir } 8 \text { bulan ini? }\end{array}$ & $\begin{array}{l}\text { Pendapat 1: Menurut saya pembelajaran online ini } \\
\text { sangat tidak efektif karena dirumah anak-anak saya tidk } \\
\text { dapat fokus belajar } \\
\text { Pendapat 2: Menurut saya, pembelajaran online kurang } \\
\text { menyenangkan } \\
\text { Pendapat 3: Pembelajaranonline ini sama saja tidak } \\
\text { belajar, karena anak-anak lebih banyak bermain daripada } \\
\text { belajar }\end{array}$ \\
\hline 2. & $\begin{array}{l}\text { Bagaimana cara Anda mengontrol agar } \\
\text { anak dapat fokusketika belajar daring? }\end{array}$ & $\begin{array}{l}\text { Pendapat 1: Cara saya mengontrol anak agar fokus } \\
\text { ketika belajar adalah dengan mendampingi mereka } \\
\text { ketika waktu belajar yang telah ditetapkan sehingga } \\
\text { anak bisa fokus dan tidak pergi kemana-mana } \\
\text { Pendapat 2: Saya memberikan nasehat dan saran kepada } \\
\text { anak saya bahwa jika waktunya belajar harus fokus, dan } \\
\text { jika telah selesai mereka boleh bermain setelahnya }\end{array}$ \\
\hline 3. & 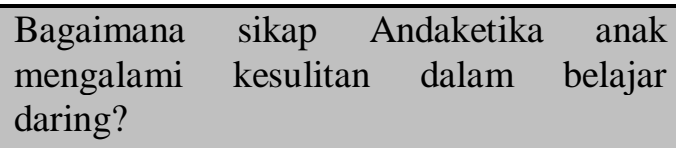 & $\begin{array}{l}\text { Ketika anak- anak mengalami kesulitan dalam belajar, } \\
\text { saya membantu dan mengajak mereka bermain agar } \\
\text { mereka tidak bosan }\end{array}$ \\
\hline 4. & $\begin{array}{l}\text { Apa yang Anda lakukan dalam mengatasi } \\
\text { kesulitan-kesulitan tersebut? }\end{array}$ & $\begin{array}{l}\text { Pendapat 1: Ketika anak saya mengalami kesulitan } \\
\text { dalam belajar secara daring saya berusaha membantu } \\
\text { sebisa yang saya mampu } \\
\text { Pendapat 2: Saat anak saya mengalami kesulitan, saya } \\
\text { berupaya membantunya dengan mencari jawaban di } \\
\text { internet } \\
\text { Pendapat } 3 \text { : Saat anak saya merasa kesulitan,saya } \\
\text { membantunya dan jika saya tidak mampu saya meminta } \\
\text { agar kakaknya dapat membimbing adiknya }\end{array}$ \\
\hline 5. & $\begin{array}{l}\text { Menurut Anda apa saja kesulitan yang } \\
\text { Anda rasakan selama mendampingi anak } \\
\text { belajar dirumah? }\end{array}$ & $\begin{array}{l}\text { Pendapat 1: Kesulitan yang saya alami adalah sulitnya } \\
\text { mengontrol anak-anak ketika belajar dari rumah } \\
\text { Pendapat 2: Saya merasa kesulitan dalam memahami } \\
\text { materi yang dipelajari oleh anak saya karena } \\
\text { tampilannya sangat berbeda dengan tampilan pelajaran } \\
\text { saya dulu } \\
\text { Pendapat 3: Saya kesulitan dalam memenuhi kebutuhan } \\
\text { yang diperlukan anak saya untuk belajar daring }\end{array}$ \\
\hline 6. & $\begin{array}{l}\text { Adakah Anda memberikan dukungan atau } \\
\text { motivasi selama anak mengikuti } \\
\text { pembelajaran daring? }\end{array}$ & Iya, tentu saja ada. \\
\hline 7. & $\begin{array}{l}\text { Seperti apakah bentuk dukungan yang } \\
\text { Anda berikan? }\end{array}$ & $\begin{array}{l}\text { Pendapat 1: Saya menyemangati anak saya agar giat } \\
\text { belajar } \\
\text { Pendapat 2: Saya berusaha untuk selalu meluangkan } \\
\text { waktu untuk mendampingi anak saya saat belajar } \\
\text { Pendapat 3: Saya berusaha untuk menyediakan segala } \\
\text { kebutuhannya selama belajar } \\
\text { Pendapat 4: Saya juga mendaftarkan anak saya untuk } \\
\text { mengikuti les untuk mengimbangi proses belajar mereka } \\
\text { Pendapat 5: Saya memberikan motivasi dengan }\end{array}$ \\
\hline
\end{tabular}




\begin{tabular}{|l|l|l|}
\hline & \multicolumn{1}{|c|}{} & $\begin{array}{l}\text { menjanjikan akan memberikan hadiah jika anak saya } \\
\text { mendapatkan hasil yang bagus dalam proses belajarnya }\end{array}$ \\
\hline $\mathbf{8 .}$ & $\begin{array}{l}\text { Seberapa sering Anda meluangkan waktu } \\
\text { untuk mendampingi anak belajar di } \\
\text { rumah? }\end{array}$ & $\begin{array}{l}\text { Pendapat 1: Saya selalu menemani anak saya saat belajar } \\
\text { Pendapat 2: Setiap malam saya selalu menyempatkan } \\
\text { waktu untuk mendampingi anak saya belajar,karena dari } \\
\text { pagi hingga sore saya bekerja }\end{array}$ \\
\hline $\mathbf{9 .}$ & $\begin{array}{l}\text { Sebagai orang tua, apakah Anda telah } \\
\text { memberikan/ menyediakan fasilitas yang } \\
\text { menunjang pelaksanaan pembelajaran } \\
\text { daring? }\end{array}$ & $\begin{array}{l}\text { Iya, tentu saja } \\
\text { Sebagai orang tua, apakah Anda berperan } \\
\text { dalam mengontrol penggunaan fasilitas } \\
\text { dengan Anda berikan digunakan sesuai }\end{array}$ \\
\hline $\mathbf{1 0 .}$ & $\begin{array}{l}\text { Pendapat 1: Ya,saya hanya memberikan gadget ketika } \\
\text { waktu-waktu tertentu dan juga saat mereka ingin } \\
\text { bermain dalam waktu yang telah saya tentukan }\end{array}$ \\
\hline
\end{tabular}

Penelitian ini merupakan penelitian deskriptif kualitatif untuk mendeskripsikan peran orang tua dalam pembelajaran daring pada siswa sekolah dasar di Pulau Rona. Pada tabel di atas menguraikan jawaban para orang tua mengenai pandangan dan peran yang mereka lakukan selama pembelajaran daring. Orang tua mengakui bahwa pembelajaran daring yang berlangsung selama ini kurang efektif. Dari peserta yang di wawancara tersebut memberikan respon yang hampir sama dengan peserta lainnya. Sehingga jawaban responden yang dijelaskan pada tabel hanya beberapa jawaban. Hampir seluruh orang tua menyatakan bahwa saat belajar dari rumah, anakanak cenderung terpengaruh oleh lingkungan sekitar. Menurut mereka, belajar di sekolah lebih efektif dan optimal jika dibandingkan dengan belajar di rumah. Meskipun orang tua telah berperan dalam mengontrol aktivitas belajar anak di rumah.

Disisi lain, para orang tua menjelaskan mengenai cara mereka dalam mengontrol aktivitas belajar anak yaitu dengan cara sebagai berikut: a) Hanya memberikan fasilitas seperti gadget pada jam belajar. b) Mengingatkan anak untuk belajar pada jadwal yang telah ditentukan. c) Menasehati anak agar tidak mudah terpengaruh oleh lingkungan sekitar. Misalnya ajakan bermain oleh teman- temannya dan bermain game saat waktu belajar.

Namun, pada situasi ini tetap ada beberapa hal yang menjadi kesulitan bagi orang tua dalam mengontrol aktivitas belajar anak di rumah. Beberapa kesulitan tersebut adalah memenuhi fasilitas belajar daring seperti membeli gadget dan kuota internet. Adapun kesulitan lain yang dialami orang tua adalah tidak memahami pelajaran yang dipelajari oleh anak-anaknya. Hal ini karena adanya perubahan kurikulum di sekolah. Oleh karena itu, untuk mengatasi hal ini orang tua mengarahkan anaknya untuk mengikuti berbagai les tambahan baik secara online maupun offline.

Selain beberapa hal yang telah dijelaskan diatas, orang tua juga memberikan dukungan kepada anak- anaknya. Adapun bentuk dukungan yang diberikan seperti meluangkan waktu untuk mendampingi anak belajar, memberi motivasi agar anak tetap semangat dalam belajar, dan mengapresiasi capaian belajar anak. Biasanya orang tua memberikan bentuk apresiasi mereka seperti memuji hasil belajar anak, memberikan hadiah dan mengajak anak mengunjungi tempat yang mereka sukai.

Dari hasil wawancara di atas, kami menemukan bahwa orang tua di Pulau Rona sangat berperan dalam pembelajaran daring. Awalnya orang tua mengakui bahwa mereka jauh lebih mendukung ketika anaknya belajar secara tatap muka di sekolah dibandingkan dengan belajar daring. Hal itu disebabkan karena adanya hambatan yang dirasakan ketika belajar dari rumah atau yang dikenal dengan belajar daring.

Saat pembelajaran daring, anak-anak mengalami kesulitan dalam memahami materi yang diberikan oleh guru. Saat mengalami kesulitan inilah orang tua memainkan perannya agar bisa membantu anak belajar dari rumah. Dari wawancara yang kami lakukan, orang tua siswa sekolah dasar di Pulau Rona menyatakan bahwa mereka selalu menyempatkan waktu untuk menemani anaknya belajar di rumah meskipun mereka mengakui bahwa mereka tidak sepenuhnya 
paham dengan materi yang dipelajari. Namun, untuk mengatasi hal ini orang tua memberikan anak- anaknya les tambahan agar lebih memahami materi pelajaran.

Selain berupaya meluangkan waktu untuk mendampingi anak, orang tua juga berusaha memenuhi segala fasilitas yang diperlukan selama pembelajaran daring seperti pengadaan gadget dan kuota internet. Para orang tua juga turut berperan dalam mengontrol aktivitas anak dalam penggunaan gadget. Mereka hanya memberikan kebebasan bermain gadget di saat anaknya belajar daring dan bermain seperlunya agar anak tidak bosan ketika belajar. Dengan kata lain, orang tua berperan dalam mengontrol aktivitas anak selama belajar di rumah.

Dalam wawancara ini, kami juga menemukan peran orang tua berupa pemberian dukungan, nasehat, serta motivasi kepada anak. Saat belajar di rumah, anak-anak masih sulit untuk fokus belajar karena beberapa faktor. Faktorfaktor yang menyebabkannya sulit fokus seperti ajakan bermain dari temannya, dan keinginan sang anak untuk menonton televisi. Untuk menyikapi hal ini, orang tua berperan dalammenasehati anak dan memberikan semangat untuk belajar. Pada wawancara ini kami juga menemukan suatu bentuk dukungan yang diberikan oleh orang tua kepada anak dengan mengapresiasi capaian belajar anak dengan memberikan hadiah. Hal ini dilakukan agar sang anak lebih giat dan semangat dalam belajar.

\section{SIMPULAN}

Berdasarkan hasil penelitian yang telah dilakukan sebelumnya, dapat ditarik kesimpulan bahwa peran para orang tua di Lingkungan Pulau Rona dalam membimbing anaknya selama di rumah sangat signifikan, dilihat dari waktu yang diluangkan oleh orang tua dalam memerhatikan dan mengontrol anaknya selama pembelajaran daring. Selain itu, orang tua di pulau rona telah berperan dalam mengatasi kesulitan yang dialami anaknya ketika pembelajaran daring serta memberikan fasilitas belajar dan motivasi kepada anaknya. Sehingga anak- anak dapat fokus dan semangat belajar walaupun dalam kondisi pembelajaran jarak jauh.

\section{DAFTAR PUSTAKA}

A, M. D., Suwardiyanto, D., Yuliandoko, H., \& W, V. A. (2017). PEMANFAATAN TEKNOLOGI SEBAGAI
MEDIA PEMBELAJARAN

DARING (ON LINE) BAGI

GURU DAN SISWA DI SMK

NU ROGOJAMPI. 2(2), 96100.

Adhe, K. R. (2018). Model Pembelajaran Daring Matakuliah Kajian PAUD di Jurusan PG PAUD Fakultas Ilmu Pendidikan Universitas Negeri Surabaya Online Learning Model PAUD Study in $P G$ PAUD Education Faculty of Surabaya State University. 1413, 26-31.

Andini, Y. T., \& Widayanti, M. D. (2020). PELAKSANAAN PEMBELAJARAN DARING PADA MASA PANDEMI COVID-19 DI TK BIAS YOGYAKARTA. 4.

Astuti, D. (2013). Analisis Peran Orang Tua dalam Meningkatkan Hasil Belajar Siswa Kelas X SMK Muhammadyah Pontianak. Journal Untan, 4(1), 64-71. http://jurnal.untan.ac.id/index. php/JPSH/article/view/22027/ 17653

Belawati, T. (2019). Pembelajaran Online (Issue December 2019).

Daulay, H. Y. (2020). JOURNAL ON TEACHER EDUCATION Research \& Learning in Faculty of Education PERANAN GURU YANG TELAH DISERTIFIKASI DALAM MENINGKATKAN MUTU PEMBELAJARAN DI SEKOLAH DASAR NEGERI 011 SUKAJADI PEKANBARU. 2, 25-38.

Dewi, W. A. F. (2020). Dampak COVID-19 terhadap Implementasi Pembelajaran Daring di Sekolah Dasar. Edukatif: Jurnal Ilmu Pendidikan, 2(1), 55-61. https://doi.org/10.31004/eduk atif.v2i1.89

Hartley, D. E. (2001). Selling E Learning. American Society for Training and 
Development.

Horton, W. K. (2001). Leading ELearning. American Society for Training and Development.

Irawati, R., \& Santaria, R. (2020). Persepsi Siswa SMAN 1 Palopo Terhadap Pelaksanaan Pembelajaran Daring Mata Pelajaran Kimia. 3(2), 264-270.

Jamil, S. H., \& Aprilisanda, I. D. (2018). PENGARUH PEMBELAJARAN DARING TERHADAP MINAT BELAJAR MAHASISWA PADA MASA PANDEMIK COVID-19. Behavioral Accounting Journal (BAJ), l(1), 62-83.

Kawuryan, M. N. (2016). Pengembangan Pendidikan Karakter Bangsa Berbasis Kearifan Lokal dalam Era MEA " Pengembangan Model Peran Orang Tua , Guru , dan Masyarakat dalam Proses Pembelajaran untuk Membentuk Intensi Berperilaku Anak Peduli Lingkungan SEMINAR NASIONAL PENDIDIKAN 2. 1.

Lynch. (2002). The Online Educator: A Guide to Creating the Virtual Classroom - 1st E.

Melia, S. (2020). JOURNAL ON TEACHER EDUCATION Research \& Learning in Faculty of Education Peran Orang tua dalam Melatih Disiplin pada Anak Tunagrahita. 2, 59-65.

Nurkolis, N., \& Muhdi, M. (2020). Keefektivan Kebijakan ELearning berbasis Sosial Media pada PAUD di Masa
Pandemi Covid-19. Jurnal Obsesi: Jurnal Pendidikan Anak Usia Dini, 5(1), 212. https://doi.org/10.31004/obses i.v5i1.535

Ramanta, D., \& Dwi Widayanti, F. (2020). Pembelajaran Daring di Sekolah Menengah Kejuruan Putra Indonesia Malang pada Masa Pandemi COVID-19. Prosiding Seminar Bimbingan Dan Konseling, $\quad O(0), \quad 61-67$. http://conference.um.ac.id/ind ex.php/bk2/article/view/81

Sari, P. (2015). Memotivasi Belajar Dengan Menggunakan ELearning. Ummul Quro, 6(Jurnal Ummul Qura Vol VI, No 2, September 2015), 20 35.

http://ejournal.kopertais4.or.i $\mathrm{d} /$ index.php/qura/issue/view/5 31

Suharsimi, A. (2007). manajemen penelitian. Rineka Cipta.

Uno, H. B. (2007). Model Pembelajaran. Bumi Aksara.

Yuangga, K. D., \& Sunarsi, D. (2020). PENGEMBANGAN MEDIA DAN STRATEGI PEMBELAJARAN UNTUK MENGATASI PERMASALAHAN PEMBELAJARAN JARAK JAUH DI PANDEMI COVID19. 4(3), 51-58. 